\title{
РОЗПОВСЮДЖЕНІСТЬ ТА ПРИЧИНИ ПІДВИЩЕННЯ АРТЕРІАЛЬНОГО ТИСКУ СЕРЕД СТУДЕНТІВ 3 КУРСУ ОДЕСЬКОГО НАЦІОНАЛЬНОГО МЕДИЧНОГО УНІВЕРСИТЕТУ
}

\author{
лікар-інтерн Швабовська Т. М., \\ к.мед.н., доцент Коломісць С. М., \\ аспірант Чернишова К. С.,
}

м. Одеса, Украӥна, Одеський наиіональний медичний університет, Кафедра пропедевтики внутрішніх хвороб та терапії

DOI: https://doi.org/10.31435/rsglobal_wos/31012019/6312

\section{ARTICLE INFO}

Received: 14 November 2018

Accepted: 21 January 2019

Published: 31 January 2019

\section{KEYWORDS}

arterial pressure,

students,

stress level,

arterial hypertension,

ketl index.

\begin{abstract}
The work is aimed at detecting episodes of increased blood pressure among third-year students of ONMed. Questionnaires, blood pressure measurements, and 525 students' stress tests were conducted. A significant percentage $(32.87 \%)$ of those who had episodes of increased pressure during the year was detected. Among them a certain number of small diseases of the thyroid gland, kidneys and obesity of the 1st and 2nd st, but most do not indicate any diseases. About half have a burdened family history of arterial hypertension. Students who had episodes of arterial hypertension elevation had a moderate to high stress level indicating psycho-emotional strain.
\end{abstract}

Citation: Швабовська Т. М., Коломієць С. М., Чернишова К. С. (2019) Rozpovsiudzhenist ta Prychyny Pidvyshchennia Arterialnoho Tysku Sered Studentiv 3 Kursu Odeskoho Natsionalnoho Medychnoho Universytetu. International Academy Journal Web of Scholar. 1(31), Vol.1. doi: 10.31435/rsglobal_wos/31012019/6312

Copyright: (C) 2019 Швабовська Т. М., Коломісць С. М., Чернишова К. С. This is an open-access article distributed under the terms of the Creative Commons Attribution License (CC BY). The use, distribution or reproduction in other forums is permitted, provided the original author(s) or licensor are credited and that the original publication in this journal is cited, in accordance with accepted academic practice. No use, distribution or reproduction is permitted which does not comply with these terms.

Вступ. Артеріальна гіпертензія (АГ) - одна 3 основних причин смертності та інвалідизації серед дорослого населення. Соціально значимою є проблема збільшення частоти зустрічаємості артеріальної гіпертензії серед молодого населення. За даними ВОЗ за останні 20 років смертність від серцево-судинних захворювань серед молодого населення (до 30 років) зросла на 5-15\%. Одною з основних причин є несвоєчасна діагностика АГ, особливо серед молодого населення. Давно доведено зв'язок стресу з розвитком АГ. Найчастіше стресового впливу, зазнає найбільш активна та працездатна частина населення. Молоді люди постійно підвержені хронічному стресу у сучасному суспільстві.

Мета: Дослідити розповсюдження та виявити причини підвищення артеріального тиску серед студентів 3 курсу ОНМедУ. Визначити рівень стресу.

Матеріали та методи: Проведено скринінгове обстеження 525 студентів 3 курсу ОНМедУ , серед них 129 чоловіків та 396 жінок. Середній вік студентів - 19,2 $\pm 2,2$ роки.

Методи дослідження: Клінічні обстеження (анкетування та опитування студентів, вимірювання АТ), оцінка тесту на виявлення рівня психологічного стресу (тест Рідера) та індексу Кетля. Поміж вищесказаного враховувались значення АТ, які студенти самостійно вимірювали на протязі року не менше 7-10 разів. 
Результати. I. На момент огляду чи в анамнезі (на протязі року) 32,87 \% студентів мали епізоди підвищеного АТ. Серед них близько третини дівчат (139 осіб - 35,1\%) та близько третини хлопців (35 осіб - 27,8\%)

II. В результати дослідження виявлено, що серед студентів 3 курсу, у яких підвищувався АТ, захворювання ЩЗ (щитовидної залози) мали 12,01 \%, ожирінням I-II ст. $16,57 \%$, захворювання нирок $-4,23 \%$, обтяжений сімейний анамнез $-43,91 \%$, підвищення АТ невідомої етіології - 52,33\%. (рис. 1 )

III. Підвищення АТ рідко (1-3 раз на рік) - 42,53 \% студентів.

У даних студентів АТ підвищувався в середньому на 20 мм.рт.ст. (в більшості до 130/90 мм.рт.ст., у 23-х до 140/90 мм.рт.ст., у 13-х до 120/85 мм.рт.ст., та в 2 студентів - до 180/120 мм.рт.ст.)

При цьому молоді люди мали такі клінічні прояви: головна біль, нудота, підвищене серцебиття, відчуття пульсації в скронях, слабкість. Більшість пов'язують дане підвищення АТ 3 психоемоційним напруженням, стресом.

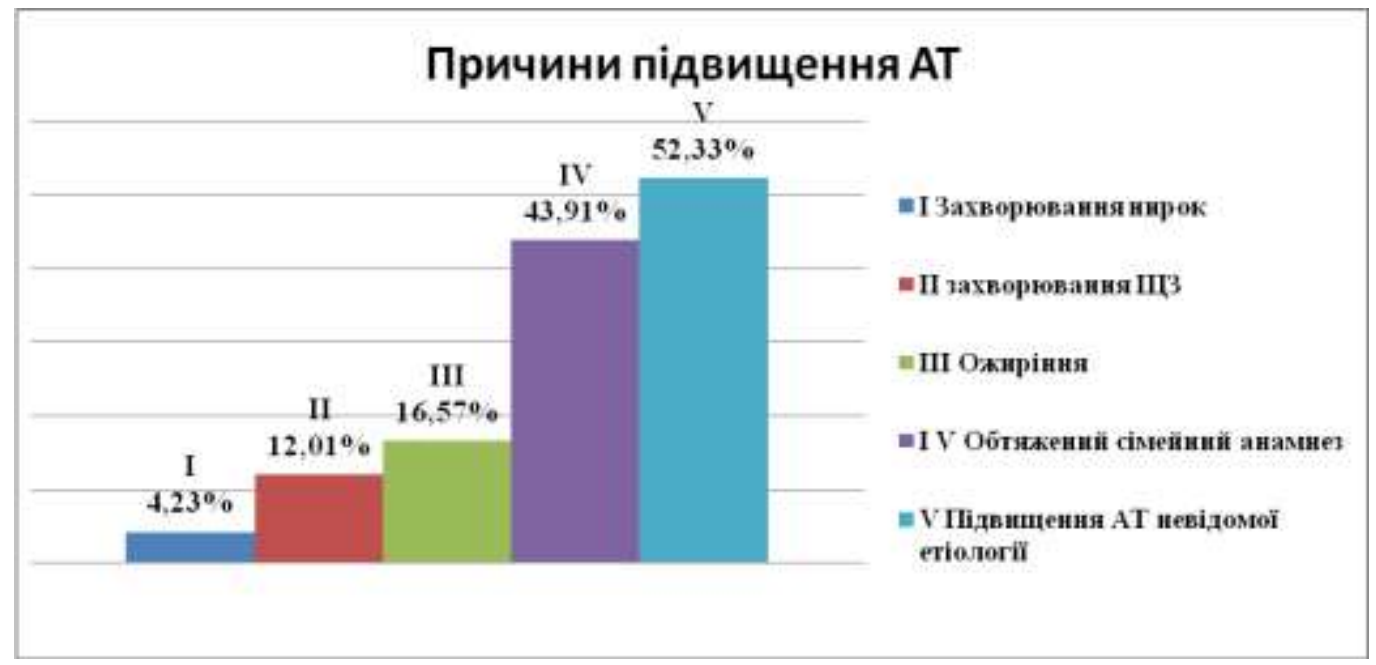

Puc 1 .

IV. Підйом АТ та погіршення самопочуття один і більше раз на тиждень $(57,47 \%)$ :

- Підйом АТ до 130/90-140/90 мм.рт.ст. - 25,21 \% студентів.

- Підйом АТ до 140/90-160/95 мм.рт.ст. - 32,26 \% студентів.

Необхідно відмітити, що у всіх студентів які мали захворювання ЩЗ та ожиріння АТ підвищувався один раз і більше на тиждень.

V. При проведенні тестування на виявлення рівня психологічного струсу (тест Рідера) серед студентів 3 курсу (525 осіб), отримано такі результати (рис.2):

- Низький рівень стресу (в межах норми) - 18,44 \% студентів,

- Середній рівень стресу $-54,05 \%$,

- Високий рівень стресу $-27,51 \%$

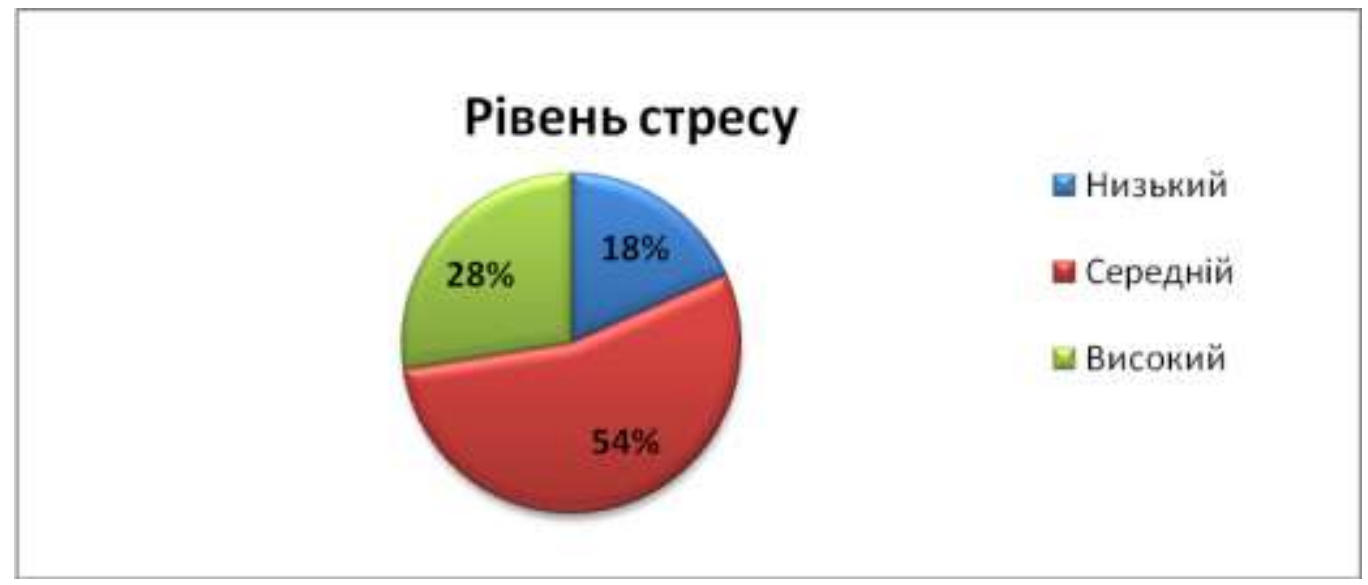

Puc 2. 
Студенти з підвищенням АТ мали високий та середній рівень стресу в рівній кількості. При цьому відзначається кореляція між рівнем стресу та підвищенням АТ. Чим вищим був рівень стресу тим вищим був підйом АТ.

Висновки. В результаті дослідження виявлено 32,87 \% студентів 3 підвищенням АТ, що являє собою надзвичайно велике значенням для даної вікової групи.

Всім студентам з підйомом АТ рекомендовано обстеження для визначення причин підвищення тиску та лікування в залежності від результатів обстеження.

На першому плані в лікуванні молодих людей 3 епізодами підвищення АТ та діагнозтованою АГ стоїть немедикаментозне лікування, а саме - зміна стилю життя. Профілактикою розвитку АТ є здоровий спосіб життя і корекцію виявлених факторів ризику. Їх модифікація спрямована на обмеження вживання солі в їжу, зменшення маси тіла при іiі надлишку, обмеження вживання алкогольних та енергетичних напоїв, жирної, копченої їжі, прянощів та солодощів, збалансоване харчування, відмову від паління, повноцінний сон, підвищення фізичної активності та психоемоційне розвантаження .

Варто завжди пам'ятати, що артеріальна гіпертензія вкрай небезпечна своїми ускладненнями, тому їі простіше попередити чим лікувати.

Всі студенти які мали епізоди підвищення АТ входять в групу ризику з розвитку АГ (деякі вже мають діагнозтовану АГ ) в майбутньому. Особливо студенти 3 підвищенням АТ 1 раз в тиждень і більше.

Крім захворювань ЩЗ та ожиріння великий вплив на розвиток АГ має хронічний стрес та психоемоційне перевантаження. Особливо йому підвержені молоді люди 3 даної групи дослідження. У всіх студентів, які мали епізоди підвищення АТ, показники стресу були середнього та високого рівня. Тому що 3 курс медичного університету є одним 3 найтяжчих за 6 років навчання, дані студенти постійно зазнають стресового впливу.

За результатами тесту Рідера, особам які мають середній рівень стресу необхідні комплексні заходу для виходу із стресу. Вони знаходяться на порозі депресії, апатії чи нервового зриву. Студентам, які мають високий рівень стресу необхідна консультація спеціаліста та лікування.

\section{ЛIТЕРАТУРА}

1. $2018 \mathrm{ESC} / \mathrm{ESH}$ Guidelines for the management of arterial hypertension /

2. Bryan Williams Giuseppe Mancia Wilko Spiering Enrico Agabiti Rosei Michel Azizi Michel Burnier Denis L Clement Antonio Coca Giovanni de Simone Anna Dominiczak etc. // European Heart Journal, Volume 39, Issue 33, 1 September 2018, Pages 3021-3104, https://doi.org/10.1093/eurheartj/ehy339

3. Афанасьева ЕЮ, Беганова ТВ. Восстановительная коррекция с применением немедикаментозных методов при лабильной артериальной гипертензии у лиц молодого возраста. Терапевт. 2012;(2):18-20.

4. Беловол АН, Князькова ИИ, Цыганков АИ, Бабак МО, Несен АА, Мазий ВВ, и др. Морфофункциональное состояние сердца и сосудов у больных молодого возраста с артериальной гипертензией. Ліки України. 2014;(9):74-9.

5. Ватутин НТ, Склянная ЕВ. Распространенность артериальной гипертензии и факторов риска у лиц молодого возраста. Архивъ внутр. медицины. 2017;7(1):30-4.

6. Гандзюк ВА, Дячук ДД, Кондратюк НЮ. Динаміка захворюваності та смертності внаслідок хвороб системи кровообігу в Україні (регіональний аспект). Вісн. проблем біології і медицини. 2017;(2):319-23.

7. Долгих ВВ, Колесникова ЛИ, Леонтьева ИВ, Бугун ОВ, Баирова ТА, Бимбаев АБЖ. Эссенциальная артериальная гипертензия у подростков: клинико-функциональные варианты и молекулярногенетические маркеры. Новосибирск: Наука; 2013. 336 с.

8. Кисляк О.А., Сторжаков Г.И., Петрова Е.В. Суточное мониторирование артериального давления у подростков и лиц молодого возраста // Росс. мед. журн. 2004; 3: С. 49-51.

9. Коваленко ВМ, Корнацький ВМ, редактори. Хвороби системи кровообігу як медико-соціальна і суспільно-політична проблема: аналітично-статистичний посібник. Київ: Коломіцин В.Ю.; 2014. 278 с.

10. Лямина НП, Наливаева $\mathrm{AB}$, Сенчихин ВН, Липчанская ТП. Маскированная артериальная гипертензия у лиц молодого возраста: выявляемость, выраженность кардиоваскулярных факторов риска и прогноз с учетом гендерных различий. Рос. кардиол. журнал. 2017;(4):7-12.

11. Рудь ОМ, Хіміон ЛВ. Артеріальна гіпертензія в пацієнтів молодого віку з ожирінням. Україна. Здоров'я нації. 2016;(1/2):234-55.

12. Самородская ИВ, Болотова ЕВ, Бойцов С.А. "Парадокс ожирения" и сердечно-сосудистая смертность. Кардиология. 2015;55(9):31-6.

13. Чернова ИМ, Лукьянов ММ, Сердюк СЕ, Бойцов СА. Оценка клинико-генетических факторов риска развития артериальной гипертензии у лиц до 35 лет. Рос. кардиол. журн. 2015;20(4):32-7. 
14. Шапошник ИИ, Синицын СП, Бубнова ВС, Чулков ВС. Артериальная гипертензия в молодом возрасте. М.: Медпрактика-М; 2011. 140 с.

15. Щупина МИ, Нечаева ГИ, Повстяная АН, Семенкин АА. Ранняя диагностика артериальной гипертензии у лиц молодого возраста. Лечащий врач. 2015;(2):22-9.

16. Assadi F. The growing epidemic of hypertension among children and adolescents: a challenging road ahead. Pediatr Cardiol. 2012 Oct;33(7):1013-20.

17. Cohen DL, Townsend RR. Approach to the young patient with new-onset hypertension. Clin J Am Soc Nephrol. 2018 Jun 7;13(6):929-932. doi: 10.2215/CJN.13341217.

18. Drukteinis JS, Roman MJ, Fabsitz RR, Lee ET, Best LG, Russell M, et al. Cardiac and systemic hemodynamic characteristics of hypertension and prehypertension in adolescents and young adults: the Strong Heart Study. Circulation. 2007 Jan 16;115(2):221-7.

19. Ghazi L, Oparil S, Calhoun DA, Lin CP, Dudenbostel T. Distinctive risk factors and phenotype of younger patients with resistant hypertension: age is relevant. Hypertension. 2017 May;69(5):827-835. doi: 10.1161/HYPERTENSIONAHA.116.08632.

20. Lee EY, Yoon KH. Epidemic obesity in children and adolescents: risk factors and prevention. Front Med. 2018 Oct 2. doi: 10.1007/s11684-018-0640-1.

21. Mangena P, Saban S, Hlabyago KE, Rayner B. An approach to the young hypertensive patient. S Afr Med J. 2016 Jan;106(1):36-8.

22. Walter van der Merwe, Veronica van der Merwe. Hypertension in young adults// New Zealand Medical Journal/ 20 February 2015, Vol 128 No 1409, P. 75-77.

23. Wang X, Snieder H. Assessing genetic risk of hypertension at an early age: future research directions. Expert Rev Cardiovasc Ther. 2017 Nov;15(11):809-812. doi: 10.1080/14779072.2017. 